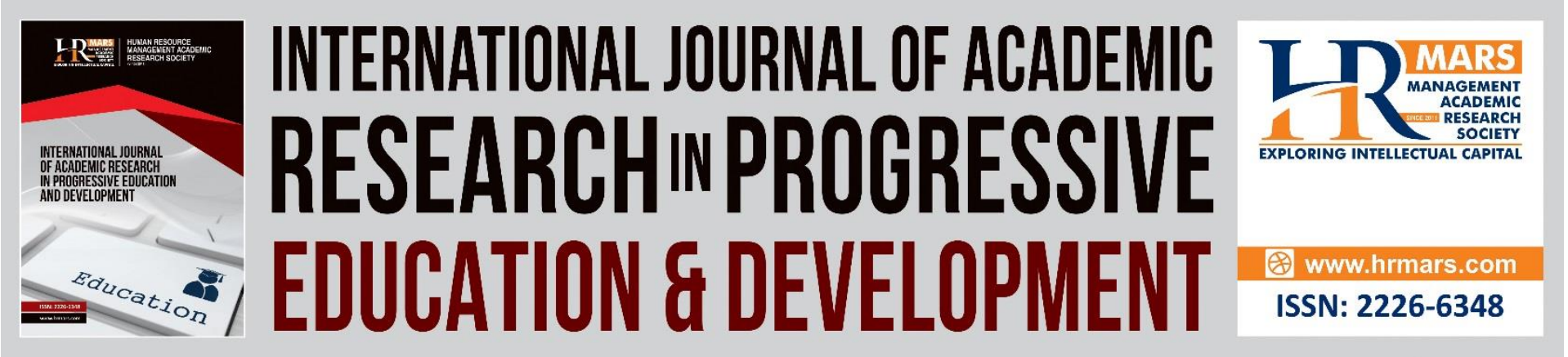

\title{
Effectiveness of Health Education Assessment Module (MoPPK) among Year Four Student in Primary School
}

Faiznur Maisya Binti Annur Sani, Azali Bin Rahmat, Gunathevan a/l Elumalai

To Link this Article: http://dx.doi.org/10.6007/IJARPED/v11-i1/12043 DOI:10.6007/IJARPED/v11-i1/12043

Received: 12 November 2021, Revised: 16 December 2021, Accepted: 05 January 2022

Published Online: 25 January 2022

In-Text Citation: (Sani et al., 2022)

To Cite this Article: Sani, F. M. B. A., Rahmat, A. Bin, \& Elumalai, G. a/I. (2022). Effectiveness of Health Education Assessment Module (MoPPK) among Year Four Student in Primary School. International Journal of Academic Research in Progressive Education and Development, 11(1), 395-402.

Copyright: (c) 2022 The Author(s)

Published by Human Resource Management Academic Research Society (www.hrmars.com)

This article is published under the Creative Commons Attribution (CC BY 4.0) license. Anyone may reproduce, distribute, translate and create derivative works of this article (for both commercial and non-commercial purposes), subject to full attribution to the original publication and authors. The full terms of this license may be seen at: http://creativecommons.org/licences/by/4.0/legalcode

Vol. 11(1) 2022, Pg. 395 - 402

http://hrmars.com/index.php/pages/detail/IJARPED

JOURNAL HOMEPAGE

Full Terms \& Conditions of access and use can be found at

http://hrmars.com/index.php/pages/detail/publication-ethics 


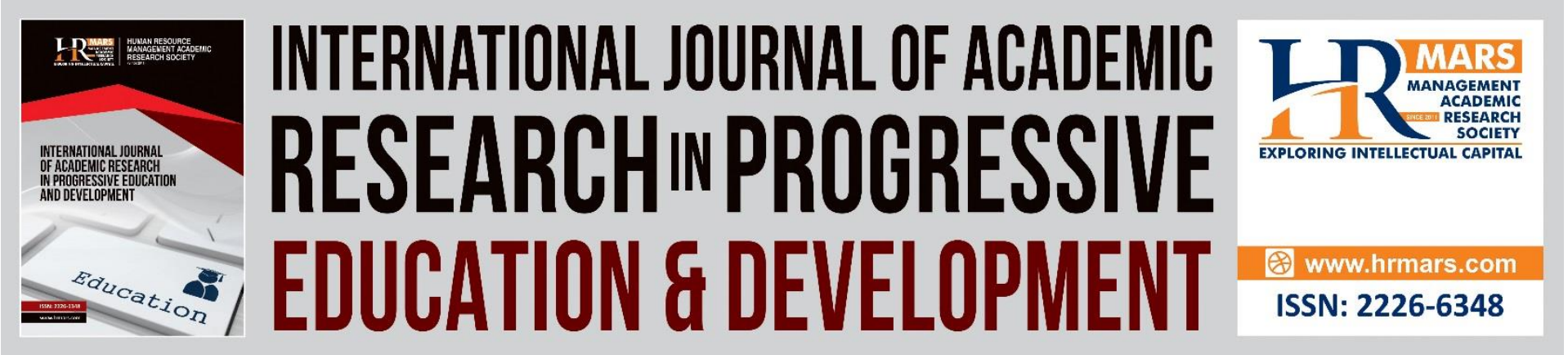

\title{
Effectiveness of Health Education Assessment Module (MoPPK) among Year Four Student in Primary School
}

\author{
Faiznur Maisya Binti Annur Sani \\ Universiti Pendidikan Sultan Idris, Tanjong Malim, Perak. \\ Email: qequr4@gmail.com
}

\begin{abstract}
Azali Bin Rahmat, Gunathevan a/l Elumalai
Fakulti Sains Sukan dan Kejurulatihan, Universiti Pendidikan Sultan Idris, Tanjong Malim, Perak.

Email: azali@fsskj.upsi.edu.my, gunathevan@fsskj.upsi.edu.my
\end{abstract}

\begin{abstract}
This quantitative research was conducted to determine the effectiveness of assessment module for Health Education subject. It was tested by comparing the posttest score using summative assessment between control and experimental group. The design used in this research is one shot case study. A total of 194 Year 4 students were randomly selected stratified as the study sample which is 95 students from control group 99 students from experimental group. The summative test was used to determine the effectiveness of Health Education Assessment Module (MoPPK). During the learning process, two groups students were given two types of assessment module separately which is the MoPPK and the PBS that was developed by curriculum development section (BPK). Data were analyzed using dependent $t$ test to state the mean difference between control and experimental group. The result shows a higher percentage of student achievement in summative test for the treatment group compare to the control group. Furthermore, independent sample t-test showed that there was a significant difference in the mean score of the summative test between the PBS control group $(M=62.64, S D=15.79)$, and the MoPPK treatment group $(M=87.86, S D=7.93)$. Hence, this clearly shows that the effectiveness of the MoPPK assessment module is stimulating and the content of the assessment is comprehensive by covering all the topics studied in the subject of Health Education.
\end{abstract}

Keywords: Effectiveness, Assessment, Health Education

Introduction

The implementation of school -based assessments is now considered important as these assessments guarantee the future of students to determine a bright future. In the field of education, the implementation process of assessment is considered a must for all subjects to 
ensure that the level of mastery of students is achieved optimally. Apart from that, the implementation of this assessment is in line with the intentions set by the Ministry of Education Malaysia through the Malaysian Education Development Plan (PPPM) 2013-2025.

Assessment can provide immediate feedback for teachers to improve teaching techniques according to the learning styles of their students. Besides, it also can gather relevant information about student performance or progress, or to determine student interests to make judgments about their learning process. There are two types of assessment that has been used in early education for primary school which is formative assessment and summative assessment. Both types of assessment have their own pros and cons. The purpose of formative assessment is to guide students' learning processes and improve students' learning out-comes. (Schildkamp et al., 2020). While summative assessment is an appraisal learning at the end of every sub unit to compares student knowledge or skills against standards (States et al., 2018). This indicates both assessments are related to each other with similar goals based on learning objectives outcomes (Dolin et al., 2018). Nevertheless, even though these assessments have their same goals in learning process but stills their differences can be seen by the way how teachers assessing their students.

However, assessment planning is very necessary to ensure that the content of the assessment covers all topics. Therefore, teachers need to plan in advance in implementing activities in assessment. The preparation of the assessment module is one of the best steps as an initial preparation for inviting students. In addition, teachers can also provide complete assessment modules in accordance with the standard documents of the education curriculum of the subjects taught. Thus, through the assessment modules provided will be able to be expanded so that the assessment process in all schools is consistent and achieve the standards set by the curriculum development division in Malaysia.

In the health education curriculum, the assessment process is getting less attention among students and teachers. This is because teachers are less exposed to assessment practices to implement the actual assessment process. In addition, time constraints and workload are factors that cause teachers to not be able to provide assessment modules that cover various aspects perfectly. In addition, students are becoming less and less interested in the subject of Health Education because it is seen as not giving importance to them because the emphasis on the importance of this subject is less and less.

Therefore, the preparation of standard assessment modules has been produced to solve this problem by helping teachers to use assessment modules that achieve the standard and consistent for the subject of Health Education. The Health Education assessment module (MoPPK) has been produced as an alternative solution to achieve the standards and guidelines for the implementation of school -based assessment. This module has demonstrated the value of validity and reliability that can be adopted as an assessment instrument that is very suitable for use in the subject of Health Education (Sani et al.2021). The construction of this MoPPK assessment module covers three main components, namely PEERS, Nutrition and First Aid and involves a comprehensive assessment, namely cognitive, psychomotor and affective. The development of the current module is guided in the instructional systems design (ISD) which is ADDIE model as elaborated by Rosset, (1987). Therefore, this assessment module MoPPK is considered as the most suitable method in enhancing students' high-level cognitive thinking in application, analysis and assessment in history.

Through the construction of this assessment module, the effectiveness needs to be evaluated to ensure that the instruments built are appropriate and meet the set learning 
DEVELOPMENT

Vol. 11, No. 1, 2022, E-ISSN: 2226-6348 @ 2022 HRMARS

objectives. Therefore, a summative assessment instrument was used to look at the effectiveness of the assessment modules built through student achievement.

Based on the identified problems, the researchers have used summative assessment instrument on two groups to see the effectiveness of the assessment modules used by students, the existing module for the control group (PBS Module) and the built -in module for the treatment group (MoPPK Module).

The purposes of the study are as below:

- etermine the effectiveness of Health Education Assessment Module (MoPPK) and PBS Assessment Module

- Determine the differences of student's achievement of Health Education Assessment Module (MoPPK) and PBS Module among gender

\section{Literature Review}

\section{Assessment for Learning}

Assessment for learning ( $\mathrm{AfL}$ ) is a process of student being self -regulated, independent and able to apply their knowledge in daily life. This type of assessment has been introduced by Black and Wiliam, (2009) saying that AfL is the best way in improving learning and raising standards. In addition, it showed that formative assessment is the heart of effective teaching, strong positive effect on achievement and raises standards (Hargreaves, 2005). While helping teachers with collecting student's data throughout assessment throughout formative, it also can build confidence among student

\section{Research Design}

This design used in this research is quasi-experiment that has treatment group and control group. The treatment group implemented MoPPK assessment module in teaching and learning Health Education while the control group implemented the school based assessment module. The aim of using MoPPk assessment module is to improve student achievement in every subtopic of Health Education subject. The sample of this study involved 194 respondents in 3 control classes (95 students) and 3 treatment classes (99 students) from six government schools. The experiments took 9 weeks to be completed. The study used a set of questions to measure the understanding of Health Education content and the effectiveness of MoPPK assessment module. The number of respondents for both groups in this study are: 63 Malay students, 67 Indian and 64 Chinese students.

\section{Data Analysis}

The data was analyzed using a descriptive statistics and independent sample t-test analysis in order to determine the levels and the differences of the constructs studied. The descriptive analysis was interpreted based on standards set by the Examination Board through the School Examination Analysis System from Ministry of Education Malaysia. Percentage scores between 0 and 39 are considered as did not achieve maximum score, percentage scores between 40 and 49 are considered as achieve maximum score, percentage scores between 50 and 64 are considered as satisfactory, and percentage scores between 65 and 79 are considered as good and percentage scores between 80 and 100 are considered as excellent. The differences were analysed based on summative assessment scores in terms of analysis and evaluation for both groups of post-test. 


\section{Research Findings}

Based on the analysis results, table 1 shows the analysis of mean and standard deviation for summative test by school category for the group using MoPPK and PBS assessment modules. The results of the analysis showed that for the treatment group that used the MoPPK assessment module, the highest mean value was from SJKC which was $M=89.68, \mathrm{SD}$ $=8.89$ and the lowest was from SJKT with a mean value of $\mathrm{M}=85.68, \mathrm{SD}=7.88$. Meanwhile, for the control group that used the PBS assessment module, the highest mean value showed SK which is $M=75.00, S D=8.34$ and the lowest was $M=47.28, S D=14.26$ which is from SJKT. The mean difference between the treatment and control groups that showed a significant difference and the highest was SJKT which was -38.41 , while the lowest difference was SK which was -13.09 .

Table. 1 Analysis of Mean and Deviation of Student Achievement for Summative Test by School Category Using MoPPK and PBS Assessment Modules

\begin{tabular}{|c|c|c|c|c|c|c|}
\hline \multirow[t]{2}{*}{ GROUP } & \multirow[t]{2}{*}{ SCHOOLS } & $M$ & \multirow[t]{2}{*}{ SD } & MEAN & \multirow[t]{2}{*}{$\mathrm{T}$} & \multirow[t]{2}{*}{$P$} \\
\hline & & & & DIFFERENCE & & \\
\hline \multirow{5}{*}{$\begin{array}{l}\text { Treatment } \\
\text { (MoPPK) } \\
\text { N-99 }\end{array}$} & SK & 88.09 & 6.53 & -13.09 & -6.88 & .000 \\
\hline & SJKT & 85.68 & 7.88 & -38.41 & - & .000 \\
\hline & & & & & 13.33 & \\
\hline & SJKC & 89.68 & 8.89 & -23.37 & - & .000 \\
\hline & & & & & 10.74 & \\
\hline \multirow{4}{*}{$\begin{array}{l}\text { Control } \\
\text { (PBS) } \\
\mathrm{N}-95\end{array}$} & SK & 75.00 & 8.34 & -13.09 & -6.88 & .000 \\
\hline & SJKT & 47.28 & 14.26 & -38.41 & - & .000 \\
\hline & & & & & 13.33 & \\
\hline & SJKC & 66.30 & 8.92 & -13.09 & -6.88 & .000 \\
\hline
\end{tabular}

Table. 2 Number of Students by Grade and Percentage of Mastery Level of Summative Test of Year 4 Pupils Between MoPPK and PBS by PBS School Category

\begin{tabular}{lllllll}
\hline GREDE & $\begin{array}{l}\text { MOPPK } \\
\text { SK }\end{array}$ & $\begin{array}{l}\text { PBS } \\
\text { SK }\end{array}$ & $\begin{array}{l}\text { MOPPK } \\
\text { SJKT }\end{array}$ & $\begin{array}{l}\text { PBS } \\
\text { SJKT }\end{array}$ & $\begin{array}{l}\text { MOPPK } \\
\text { SJKC }\end{array}$ & $\begin{array}{l}\text { PBS } \\
\text { SJKC }\end{array}$ \\
\hline A & 25 & 10 & 22 & & 25 & 2 \\
$80-$ & $(75.76 \%)$ & $(33.33 \%)$ & $(68.75 \%)$ & & $(73.53 \%)$ & $(6.06 \%)$ \\
100 & & & & & & \\
B & 7 & 19 & 10 & 4 & 9 & 19 \\
$65-79$ & $(21.21 \%)$ & $(63.33 \%)$ & $(31.25 \%)$ & $(12.50 \%)$ & $(26.47 \%)$ & $(57.58 \%)$ \\
C & 1 & 1 & & 11 & & 10 \\
$50-64$ & $(3.03 \%)$ & $(3.33 \%)$ & & $(34.38 \%)$ & & $(30.30 \%)$ \\
D & & & & 8 & & 2 \\
$40-49$ & & & & $(25.00 \%)$ & & $(6.06 \%)$ \\
E & & & & 9 & & \\
$0-39$ & & & & $(28.13 \%)$ & & \\
& & & & & &
\end{tabular}

Table 2 shows the percentage and number of student achievement by grade for the summative test of the level of mastery of fourth year students between MoPPK and PBS by 
school category. The results showed that the achievement of the summative test and the number of students who obtained grade A for the MoPPK SK group was twenty -five people (75.76\%), grade B seven people (21.21\%) and grade C one person (3.03\%) while for the PBS SK group the number of students who got grade A were ten people $(33.33 \%)$, grade B was nineteen people $(63.33 \%)$ and grade $C$ was one person (3.33\%).

Furthermore, for SJKT, the findings show that the achievement of the summative test and the number of students who obtained grade A for the MoPPK group was twenty -two people $(68.75 \%)$ and grade B ten people (31.25\%). While for the PBS group the number of students who got grade $B$ was four people (12.50\%), grade $C$ was eleven people (34.38\%), grade D was eight people (25\%) and grade E was nine people (28.13\%).

The analysis for SJKC showed that the achievement of the summative test of the MoPPK group for grade A was twenty -five people (73.53\%) and grade B was nine people (26.4\%). While the PBS group for grade A was two people $(6.06 \%)$, grade B was nineteen people $(57.58 \%)$, grade $C$ was ten people $(30.30 \%)$ and grade $D$ was two people $(6.06 \%)$

Table. 3 Analysis of Mean and Deviation of Pupil Achievement for Summative Test of Control Group and Treatment Group

\begin{tabular}{llllll}
\hline $\begin{array}{l}\text { TYPE } \\
\text { ASSESSMENT }\end{array}$ & GROUP & N & MIN & SD & $\begin{array}{l}\text { STD. } \\
\text { ERROR } \\
\text { MEAN }\end{array}$ \\
\hline $\begin{array}{l}\text { SUMMATIVE } \\
\text { TEST }\end{array}$ & $\begin{array}{l}\text { CONTROL } \\
\text { GROUP } \\
\text { (PBS) }\end{array}$ & $\mathbf{9 5}$ & $\mathbf{6 2 . 6 4}$ & $\mathbf{1 5 . 7 9}$ & $\mathbf{1 . 6 2 0 2 7}$ \\
& $\begin{array}{l}\text { TREATMENT } \\
\text { GROUP } \\
\text { (MOPPK) }\end{array}$ & $\mathbf{9 9}$ & $\mathbf{8 7 . 8 6}$ & $\mathbf{7 . 9 3}$ & $\mathbf{. 7 9 6 6 9}$ \\
& & & & \\
\hline
\end{tabular}

Table. 4 Analysis of Independent Sample T Test of Student Achievement for Summative Test of PBS Control Group and MoPPK Treatment Group

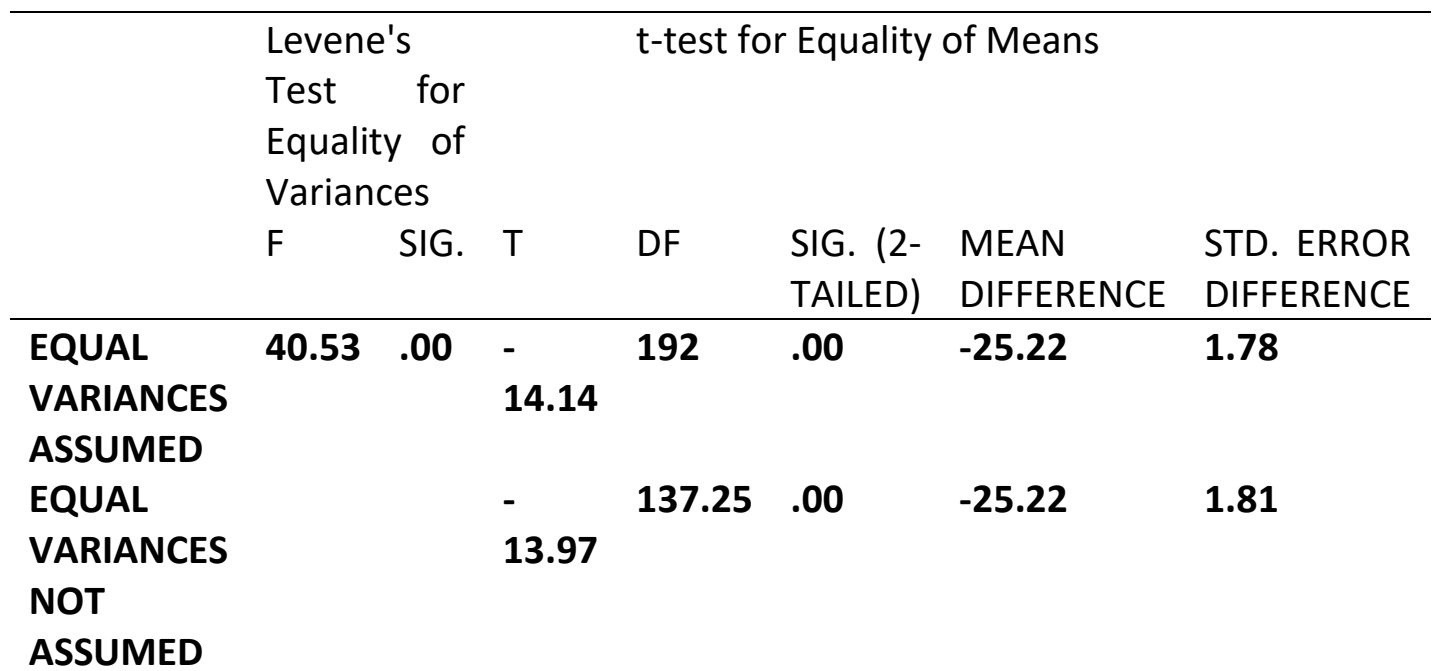

Tables 3 and 4 above show the independent sample t-test analysis to compare the mean scores of the summative test between the control group that is those who went through the 
PBS assessment module and the treatment group that went through the MoPPK assessment module. The results show that the value of $t(137.25)=-13.97, p=.00$ is significant. The test results showed that there was a significant difference in the mean score of the summative test between the PBS control group ( $M=62.64, S D=15.79)$, and the MoPPK treatment group $(\mathrm{M}=87.86, \mathrm{SD}=7.93)$.

\section{Discussion}

\section{What is the effectiveness of the MoPPK Module?}

Findings of the study through independent t test to see the difference in achievement of fourth year students for both control group and treatment group at 0.05 confidence level showed that there is a significant difference for summative test of students using MoPPK assessment module and PBS assessment module. Findings show that the mean value of the summative test achievement level of students in the treatment group using MoPPK is higher than that of students in the control group using the PBS assessment module. In addition, the achievement of the summative test mastery level of students who use the MoPPK assessment module is at an excellent performance standard compared to students who use the PBS assessment module. This indicates that the effectiveness of the use of the MoPPK assessment module is very positive.

The use of summative tests was used to compare the overall level of mastery of the topics for the Health Education subjects that had been studied. Therefore, standard reinforcement tests covering all topics were used to make assessments for both groups. The findings of this study can be seen that the use of assessment of learning is very suitable to be used to assess the level of mastery of students and the results obtained are not influenced by other factors (Thomas, 2018).

Furthermore, the findings of the study of Kibble, (2017) and Harrison et. al. (2016) show that through summative assessment can improve the assessment modules used in subjects, looking at the effectiveness of learning and assessment for accreditation purposes. The treatment group also showed a very excellent effect after going through a continuous assessment process using MoPPK compared to the control group. In this regard, this clearly shows that through the MoPPK assessment module, students can improve the overall level of mastery of each learning standard in Health Education well.

\section{Conclusion}

As conclusions, the effectiveness of this module can be seen to show a positive effect on the level of mastery of students for the subject of Health Education. In addition, the usability of this module is very complementary to each other in terms of assessment because it includes summative and formative assessment. The improvements that have been modified from the PBS module based on the Education Curriculum Standard Document have shown a very satisfactory improvement among the students undergoing the treatment process.

The researcher hopes that through the implementation of this module, it will be possible to create a standardized assessment for Health Education subjects in primary schools as soon as it can fulfill the guide line established by the Ministry of Education Malaysia which is by implementing a comprehensive assessment for student in every subject. In additional, more in depth study can be done by producing a translation of the MoPPK assessment module into English version so that it can be used in further research globally through health education system. 
DEVELOPMENT

Vol. 11, No. 1, 2022, E-ISSN: 2226-6348 @ 2022 HRMARS

\section{Acknowledgment}

The author would like to express their highest appreciation to the panel of legal expert contents of the MoPPK Module and also given to the academics who have provided guidance in the process of development this module.

\section{References}

Black, P., \& Wiliam, D. (2009). Developing the theory of formative assessment. Educational Assessment, Evaluation and Accountability, 21(1), 5-31. https://doi.org/10.1007/s11092-008-9068-5

Dolin, J., Black, P., Harlen, W., \& Tiberghien, A. (2018). Exploring Relations Between Formative and Summative Assessment, (October 2019), 53-80. https://doi.org/10.1007/978-3319-63248-3 3

Hargreaves, E. (2005). Assessment for learning? Thinking outside the (black) box. Cambridge Journal of Education, 35(2), 213-224. https://doi.org/10.1080/03057640500146880

Harrison, C. J., Könings, K. D., Dannefer, E. F., Schuwirth, L. W. T., Wass, V., \& van der Vleuten, C. P. M. (2016). Factors influencing students' receptivity to formative feedback emerging from different assessment cultures. Perspectives on Medical Education, 5(5), 276-284. https://doi.org/10.1007/s40037-016-0297-x

Kementerian Pendidikan Malaysia. (2018). Dokumen Standard Kurikulum Pendidikan: Pendidikan Kesihatan, 1-6.

Kibble, J. D. (2017). Best practices in summative assessment. Advances in Physiology Education, 41(1), 110-119. https://doi.org/10.1152/advan.00116.2016

Rossett, A. (1987). Training Need Assessment. Englewood Cliffs: Educational Technology Publications.

Sani, F. M. A., Rahmat, A., \& Elumalai, G. (2021). Validity and Reliability of the Health Education Assessment Module (MoPPK) among Primary Students in Malaysia. International Journal of Academic Research in Progressive Education \& Development, 10(1) 2020, Pg. 130 - 138. https://doi.org/10.6007/IJARPED/v10-i1/8378

Schildkamp, K., Van der Kleij, F. M., Heitink, M. C., Kippers, W. B., \& Veldkamp, B. P. (2020). Formative assessment: A systematic review of critical teacher prerequisites for classroom practice. International Journal of Educational Research, 103(May), 101602. https://doi.org/10.1016/j.ijer.2020.101602

States, J., Detrich, R., \& Keyworth, R. (2018). Summative Assessment ( Wing Institute Original Paper ), (March). https://doi.org/10.13140/RG.2.2.16788.19844

Thomas, J. W. (2018). The effects of formative and summative assessment on student's connectedness, satisfaction, learning and academic performance within an online healthcare course. Core, (August). 